\title{
The Research on Comprehensive Financial Crisis Early-warning Model of Chemical Public Companies
}

\author{
Li Wang ${ }^{1, a}$ and XiangGuo $\mathrm{Li}^{2, \mathrm{~b}}$ \\ ${ }^{1}$ Li Wang, Wuhan University of Technology School in China \\ ${ }^{2}$ Xiangguo Li, Wuhan University of Technology School in China \\ a4441223108@QQ.com, $\left.{ }^{\mathrm{b}} 422025867 @ Q Q . c o m\right)$
}

\section{Keywords: Equity structure; Chemical industry; Financial early-warning}

\begin{abstract}
The financial early warning research has always been more of a topic, along with the market economic development, and financial early warning model research is more and more refined to every industry. It can help enterprise to predict the future development, through the study of financial early warning model for every industry, For example, if enterprises have a potential crisis, timely financial remedy can save them. Previous scholars have also a lot of research on the chemical industry, but through the combination of quantitative and qualitative analysis of the chemical industry listed company about financial early warning model research is less than any other industry. This article selects 10 ST chemical industry enterprises with 10 non ST companies as the research sample. It analyzes the financial situation of 2013-2015 ST enterprises by significance test and correlation test screening of financial indicators to establish a Fisher discriminate financial early warning model. At the same time, comprehensive financial early warning mode is conducted by the Fisher financial early warning model combining with equity structure non-financial indicators, and using Fisher discriminate analysis 1. This article will select 40 sample data into Fisher financial early warning model and Fisher 1 comprehensive financial early warning model for judging the effectiveness of the early warning model and Fisher1 comprehensive financial early warning model to predict ability is more effective than Fisher financial early warning model prediction.
\end{abstract}

\section{Introduction}

Financial risk refers to the enterprise's financing structure is irrational, solvency decreased, making the company expected to decline in profitability, and investors hold a pessimistic attitude to the future of the enterprise. If financial risk is not properly controlled, companies will fall into financial risk, and ultimately to withdraw from the market. With the continuous research on the financial early warning model, the financial early-warning model has evolved from the single-variable early-warning model, the multiple linear analysis to the BP neural network and the Logistic regression analysis to the complete financial early-warning theory system ${ }^{[1]}$. There are many factors that affect the financial distress of the enterprise, including the macro environment and the enterprise's own management mistakes, such as imperfect capital market, management decision-making mistakes, weak risk awareness, and many more. Therefore, if the enterprises want to achieve long-term sustainable development, they have to pay attention to the control of risk. The enterprises can use the financial early warning model to establish a standardized risk aversion mechanism to avoid the enterprise into financial distress.

The financial crisis may be caused by financial activities or may be affected by non-financial activities. In the study of financial early-warning model, the selection of indicators should not be limited to financial indicators. It should also consider the impact of non-financial indicators on corporate financial crisis. This paper discusses the impact of ownership structure on the financial early warning of enterprises. At the same time, the early warning model based on financial indicators and the early warning model of equity structure are used to construct comprehensive financial early warning model. 


\section{Research Design}

Sample Data Selection. In this paper, a sample of chemical companies listed in Shanghai and Shenzhen stock exchanges is selected as the research sample, including 10 ST companies, and 10 non-ST companies that have never been ST have been selected as the estimated sample, according to the matching proportion of 1:1, At the same time selected 40 listed companies (including ST companies and non-ST companies) as a test sample.ST companies mainly refer to the companies with abnormal financial status, including the enterprise's consecutive loss in the last two accounting years; the certified public accountant cannot express the report of the last fiscal year opinions or reservations of the audit report ${ }^{[2]}$. In order to establish a financial early-warning model, this paper sets up ST listed companies to be specially treated in t years, collecting 40 listed companies in the previous year and two years before the financial statements as a test sample, that is t-1 years And t-2 years of financial reporting data.

Index Selection. Based on the research of previous scholars, this paper selects 10 financial indicators from the five aspects of solvency, operating capacity, profitability, development capacity, cash flow capacity, and selected four representative indicators to reflect the ownership structure These indicators include Quick ratio(X1), Asset-liability ratio (X2), Accounts Receivable Turnover (X3), Inventory Turnover (X4), Operating cost ratio (X5), Return on Assets (X6), Net profit growth rate (X7), Owner's Equity Growth (X8), Net cash flow liabilities arising from operating activities (X9), Operating income Net cash (X10), Shareholding ratio of the largest shareholder (X11), Shareholding ratio of the top three shareholders (X12), the Z index (X13), Herfindahl_5 index (X14).

\section{Research Hypothesis and Model Design}

Research Hypothesis. With the continuous improvement of the capital market, the ownership structure of listed companies reflects the shareholding proportion of shareholders and the concentration of ownership, which directly affects the corporate governance structure. According to internal control theory, the corporate governance structure is closely related to operating performance, The company's operating performance and financial crisis may be related to the occurrence of ${ }^{[4]}$. Therefore, the company's ownership structure and the financial crisis are closely related to the occurrence. According to this theory, this paper proposes the following assumptions that the predictive ability of the integrated financial early warning model is higher than that of the financial early warning model alone.

Model Design. This paper uses the significance test and the correlation analysis to select suitable financial and non-financial indicators. Fisher discriminate analysis is used to construct Fisher's financial early-warning model and Fisher 1 comprehensive financial early-warning model.

The Fisher financial warning model is as follows:

$$
\mathrm{F}(\mathrm{Y}=\mathrm{i})=\beta 0+\beta 1 * \mathrm{X} 1+\beta 2 * \mathrm{X} 2+\beta 3 * \mathrm{X} 3+\ldots \ldots+\beta 10 * \mathrm{X} 10 .
$$

The Fisher 1 comprehensive financial warning model is as follows:

$$
\mathrm{F} 1(\mathrm{Y}=\mathrm{i})=\beta 0+\beta 1 * \mathrm{X} 1+\beta 2 * \mathrm{X} 2+\beta 3 * \mathrm{X} 3+\cdots+\beta 10 * \mathrm{X} 10+\beta 11 * \mathrm{X} 11+\beta 12 *
$$

$\mathrm{X} 12+\beta 13 * \mathrm{X} 13+\beta 14 * \mathrm{X} 14$

Among them : $\beta 0$ stands for constant, $\beta 1 \sim \beta 14$ stands for discriminate function coefficient; $Y=$ 0 stands for ST company, $\mathrm{Y}=1$ stands for non-ST company.

\section{Empirical Research}

Construct Fisher Fishery Distinguish Model. Based on the significance and correlation test, this paper selects the four indexes of quick ratio (X1), receivable turnover rate (X3), return on assets (X6) and net profit growth rate (X7) model. According to these data, we can get the financial distress model $\beta$ by the analysis of SPSS, and establish the financial early warning model F, we can see from Table 1 that the quick ratio, the receivable turnover rate, the net profit growth rate and the 
enterprise fall into financial And the return rate of assets is negatively correlated with the probability of financial distress.

Table 1 Coefficient of classification function

\begin{tabular}{|c|c|c|}
\hline \multirow{2}{*}{ Index } & \multicolumn{2}{|c|}{ Y } \\
\cline { 2 - 3 } & 0 & 1 \\
\hline $\mathrm{X} 1$ & 0.727 & 1.309 \\
\hline $\mathrm{X} 3$ & 0.022 & -0.01 \\
\hline $\mathrm{X} 5$ & -1.359 & -0.088 \\
\hline $\mathrm{X} 7$ & 0.296 & 0.982 \\
\hline (constant) & -2.184 & -2.698 \\
\hline
\end{tabular}

ST's financial early warning model is as follows:

$$
\mathrm{F}(\mathrm{Y}=0)=-2.184+0.727 * \mathrm{X} 1+0.022 * \mathrm{X} 3-1.359 * \mathrm{X} 5+0.296 * \mathrm{X} 7 \ldots
$$

Non-ST financial early warning model is as follows:

$$
\mathrm{F}(\mathrm{Y}=1)=-2.698+1.309 * \mathrm{X} 1-0.01 * \mathrm{X} 3-0.088 * \mathrm{X} 5+0.982 * \mathrm{X} 7 .
$$

Construct Fisher 1 Comprehensive Financial Early Warning Model. In this paper, we use the non-financial index of ownership structure to analyze the effect of abnormal financial structure on the company's financial position. He proportion of shares held by the largest shareholder determines the size of the company's holding, holding scale is divided into absolute holding and relative holding, if the largest shareholder and the proportion of more than 50\%, indicating that the company's holding scale is absolute holding, otherwise is relative holding ${ }^{[3]} . \mathrm{Z}$ index is the ratio of the largest shareholder to the second largest stockholder, $\mathrm{Z}$ refers to the governance rights of the largest shareholder. The Herfindahl_5 index is the sum of the shareholdings of the top five shareholders of tradable shares, indicating the ownership concentration of the top five shareholders of tradable shares ${ }^{[5]}$. From the correlation analysis, the paper selects these indicators including X1, $\mathrm{X} 3, \mathrm{X} 5, \mathrm{X} 7, \mathrm{X} 12, \mathrm{X} 13$. In this paper, we introduce the non-financial index of financial structure based on the Fisher financial index early-warning model, and establish the integrated financial early-warning model F1 combining financial index and non-financial index. Using the Discriminate analysis in SPSS analysis to determine the coefficient of the integrated financial early warning model F1, as shown in Table 2:

Table 2 Discriminate Analysis

\begin{tabular}{|c|c|c|}
\hline \multirow{2}{*}{ Index } & \multicolumn{2}{|c|}{ Y } \\
\cline { 2 - 3 } X1 & 0 & 1 \\
\hline $\mathrm{X} 3$ & 0.727 & 1.307 \\
\hline $\mathrm{X} 5$ & 0.004 & -0.021 \\
\hline $\mathrm{X} 7$ & -1.924 & -0.729 \\
\hline $\mathrm{X} 12$ & 0.468 & 1.174 \\
\hline $\mathrm{X} 13$ & 2.745 & 7.396 \\
\hline$($ Contact $)$ & 0.09 & 0.101 \\
\hline
\end{tabular}

ST's comprehensive financial early warning model is as follows:

$$
\mathrm{F} 1(\mathrm{Y}=0)=-9.362+0.727 * \mathrm{X} 1+0.004 * \mathrm{X} 3-1.924 * \mathrm{X} 5+0.468 * \mathrm{X} 7+2.745 * \mathrm{X} 12+
$$


The non-ST integrated financial early-warning model is as follows :

$$
\mathrm{F} 1(\mathrm{Y}=1)=-12.041+1.307 * \mathrm{X} 1-0.021 * \mathrm{X} 3-0.729 * \mathrm{X} 5+1.174 * \mathrm{X}+7.394 * \mathrm{X} 12+
$$

\section{Analysis of Model Test Results}

In this paper, 40 listed companies in the chemical industry are selected for t-1-year and t-2-year financial data as test samples, and the sample data are applied to the established financial early warning model $\mathrm{F}$ and integrated financial early warning model F1. As can be seen from Table 3, $\mathrm{t}-1$ year forecasting standard model forecasting rate of $90 \%$, comprehensive indicators of early warning model forecast accuracy rate of $92.5 \%, \mathrm{t}-2$ year forecasting model of financial forecasting model for $85 \%$, And the forecast accuracy of the comprehensive financial forecasting model is $92.5 \%$. It can be proved that hypothesis is established, and the financial early warning model of comprehensive index has higher accuracy than the early warning model of financial indicators.

Table 3 Model Test Results

\begin{tabular}{|c|c|c|c|c|c|c|c|}
\hline \multirow{2}{*}{ Period } & $\begin{array}{c}\text { ST/Non } \\
\text { ST }\end{array}$ & \multicolumn{3}{|c|}{$\begin{array}{c}\text { Early Warning Model of } \\
\text { Financial }\end{array}$} & \multicolumn{3}{|c|}{$\begin{array}{c}\text { Comprehensive index } \\
\text { early warning model }\end{array}$} \\
\hline & $\mathrm{Y}$ & 0 & 1 & Accuracy & 0 & 1 & Accuracy \\
\hline \multirow{2}{*}{$\mathrm{t}-1$} & 0 & 8 & 2 & $80.00 \%$ & 9 & 1 & $90.00 \%$ \\
\cline { 2 - 8 } & 1 & 2 & 28 & $93.33 \%$ & 2 & 28 & $93.33 \%$ \\
\hline \multirow{2}{*}{$\mathrm{t}-2$} & 0 & 8 & 2 & $80.00 \%$ & 10 & 0 & $100.00 \%$ \\
\cline { 2 - 8 } & 1 & 4 & 26 & $86.67 \%$ & 3 & 27 & $90.00 \%$ \\
\hline
\end{tabular}

\section{Conclusion}

The early warning index system based on the previous scholars, the equity structure into the financial early warning model, the index system is more predictive ${ }^{[6]}$. On the one hand, the financial indicators are not comprehensive enough to reflect the financial distress of the listed companies, and can not reflect the company's financial distress. In the meantime, the financial indicators of the listed companies are not comprehensive. On the other hand, the higher the probability of the financial crisis, the more the financial early warning model predicts the financial distress of the listed company and improves its accuracy, so that the model has more application value. Although the prediction accuracy of financial early-warning model in this paper has increased, it is also flawed: (1) The paper analyzes the financial statements of the listed companies in the chemical industry, and cannot confirm whether the financial statements have been whitewashed $^{[8]}$ If the published data are modified by human, it will affect the accuracy of the model study. In this paper, 10 ST companies with abnormal financial status and 10 non-ST companies with healthy financial status are selected as the samples, and 40 listed companies are used as the test sample data, so the sample data is less. (2) Ownership structure, in which the ownership structure and the ownership structure of the concentration of four financial indicators, selects the fewer quantitative indicators of financial to enter the financial early warning analysis of only two indicators, the accuracy of the forecast may have an impact ${ }^{[9]}$. (3) The selection criteria of the company of abnormal financial condition may be different from western scholars, western scholars mostly use bankrupt companies and non-bankrupt companies as research samples, this paper listed companies are divided into financial distress and financial health companies, and ST is defined as Financial Distress Enterprises ${ }^{[10]}$. The sample selection criteria in this paper are mainly the ST companies whose financial situation is abnormal. 


\section{References}

[1] K. SHAO: Accounting \& Finance, Vol.31 (2010) No.3, p.27 (In Chinese).

[2] F.R ZENG and X.Q Liu: Finance Monthly, Vol. 4(2010) No.4, p.25 (In Chinese).

[3] W.J ZHANG and We LUO: Financial Supervision, Vol. 1(2016) No.4, p.91 (In Chinese).

[4] K.L YUAN and YU YUN: Journal of Finance and Accounting, Vol. 12(2009) No.5, p.20 (In Chinese).

[5] D.F CAO and H.Q XIA: Journal of Northeastern University (Social Science Edition), Vol. 1(2006) No.10, p. 31 (In Chinese).

[6] Yi-long Liu, Qing HAO and Song Li: Journal of Software Institute of Technology, Vol. 2(2015)No.6, p.22 (In Chinese).

[7] H.W Yang: Journal of Business Economics, Vol. 26(2015) No. 8, p.93 (In Chinese).

[8] H. Yang: Accounting and Communications, Vol. 22(2011) No.8, p.33 (In Chinese).

[9] Y.M Liu and Li Liu: Business Research, Vol. 10(2016) No.10, p.87 (In Chinese).

[10] Y.C Li and Jing Ca: China Management Informazation, Vol. 21(2010) No.11, p.16 (In Chinese). 